\title{
ESTUDO DO SISTEMA RADICULAR DE TEPHROSIA CANDIDA D. C.
}

\section{Romeu Inforzato}

Tephrosia candida D. C., leguminosa originária da Āsia tropical (noroeste do Himalaia até a Birmânia) (5), foi introduzida no Estado de São Paulo por volta de 1930. Veio de Java, para o Instituto Agronômico de Campinas, junto com outras sementes de leguminosas importadas pelo então Diretor, Dr. Teodureto de Camargo (4).

Por se haver adaptado bem ao clima de São Paulo, alcançando nas boas terras um porte quase arbóreo ( 5 metros), vem sendo utilizada para vários fins. Plantada em linha, serve para proteção de lotes de cafeeiros contra ventos frios ; semeada nos lugares declivosos, protege o solo contra a erosão ; a parte aérea, quando sêca, constitui boa lenha ; de maior valor, é a considerável massa de fôlhas que a planta fornece ao atingir seu estado adulto. Essa massa de matéria orgânica contribui para o melhoramento físico-químico do solo.

O estudo do sistema radicular de tão útil leguminosa, dentro das condições mesológicas paulistas, ao que nos conste, não havia sido feito. Seria de grande interêsse conhecer a profundidade máxima das raízes da tefrósia, pois estas, translocando alimentos, deixa-os em boa parte à superfície do solo. Seria de valor determinar o pêso aproximado de todo sistema radicular, pois, morta a planta, as raízes são deixadas como matéria orgânica no solo.

Foi com o objetivo de elucidar essas questres que realizamos o trabalho a que se refere a presente publicação.

\section{MATERIAL E TECNICA}

Trabalhamos com exemplares de uma plantação existente na Fazenda Santa Elisa, $\left({ }^{*}\right)$ do Instituto Agronômico. O solo ali é do tipo de terra roxa misturada.

A técnica que empregamos foi a mesma usada no estudo do sistema radicular do cafeeiro (1).

(*) O presente trabalho foi executado com exemplares de uma plantaçāo de Tephrosia candida D. C., feita pelo Eng. Agrônomo Antônio José de Sousa, da Secção de Café do Instituto Agronômico, que gentilmente nô-los cedeu para execução dêste estudo. Por esta razão externamos aqui os nossos agradecimentos aquele colega. 
Nessa plantação, com 5 anos de idade, aproximadamente, escolhemos 16 plantas. Elas tinham em média cinco metros de altura. Foram cortadas rente ao solo. A $0.175 \mathrm{~m}$ das cepas, abriu-se uma valeta paralela à linha das plantas. A profundidade da cava foi até o ponto onde não mais existissem vestígios de raízes da tefrósia. A largura dessa valeta foi de $1,5 \mathrm{~m}$, suficiente para que os operários pudessem manejar livremente as ferramentas.

A parede da valeta, do lado das plantas, foi cuidadosamente trabalhada a fim de tornar-se o mais plana e vertical possível ; depois, foi desmanchada em blocos.

A fim de nivelar a camada superficial do terreno, foi tirada a primeira. fiada de blocos, os quais tinham, é claro, alturas variáveis. A seguir, foram removidas três fiadas de blocos com 10 centímetros de altura cada uma; depois, mais duas com 20 centímetros de alto. Tôdas as demais camadas. foram tiradas com 35 centímetros de altura. A parede, com 7 metros de comprimento e $3,85 \mathrm{~m}$ de altura, foi assim inteiramente desmanchada em 300 blocos de terra, sendo 20 superficiais, $60 \mathrm{com} 10 \mathrm{~cm}$ de altura, $40 \mathrm{com}$ $20 \mathrm{~cm}$ de alto, e, finalmente, $180 \mathrm{com} 35 \mathrm{~cm}$ de altura.

Cada bloco foi colocado em um saco devidamente etiquetado para. indicar sua posição no corte. A estampa 14 mostra a valeta, após a retirada. de todos os blocos. As cavidades vistas nas paredes são velhas panelas de saúvas; nelas se constatou maior adensamento de raízes da tefrósia.

Feita a coleta, foram os blocos desmanchados e peneirados para separar as raízes da terra. Lavadas, as raízes foram sêcas à sombra durante um dia, e depois pesadas com aproximação de $0,1 \mathrm{gr}$.

De posse dêstes dados, pudemos reconstituir a distribuição do sistema radicular das 16 plantas pelas diferentes camadas do solo e exprimir esta distribuição em percentagem. Foi também possivel determinar a profundidade atingida pelas raízes.

$\mathrm{Na}$ fig. 1 reproduzimos o diagrama em perfil do sistema radicular de Tephrosia candida D. C. Cada quadrinho representa um bloco retirado. do terreno e cada ponto equivale a $0,1 \mathrm{gr}$ de raiz.

O pêso total de raízes encontrado para as 16 plantas estudadas foi de $8.810,12$ gr.

Constatamos que $99,14 \%$ do pêso das raízes se encontram nos primeiros: $0,50 \mathrm{~m}$ de profundidade. $\mathrm{O}$ restante, $0,86 \%$, está entre esta última profundidade e a profundidade máxima de $3,85 \mathrm{~m}$ e é constituído por finas raízes. Esta profundidade, que reputamos apreciável para a planta em estudo, assegura-lhe umidade para a parte aérea nos períodos secos; mobiliza. os elementos das camadas profundas do solo trazendo-os à superfície.

Sôbre um pano preto, em que prèviamente foi traçado o perfil dos. blocos, distribuimos as raízes correspondentes a 7 das 16 plantas estudadas. A estampa 15 mostra-nos êste arranjo, o qual nos dá uma boa idéia da distribuição e profundidade do sistema radicular de Tephrosia candida.

Nunca será demais ressaltar o valor da transformação da matéria. orgânica no melhoramento do solo. Consulte-se Menezes Sobrinho (2). Ela se dá por processos bioquímicos levados a efeito pelos microorganismos. 


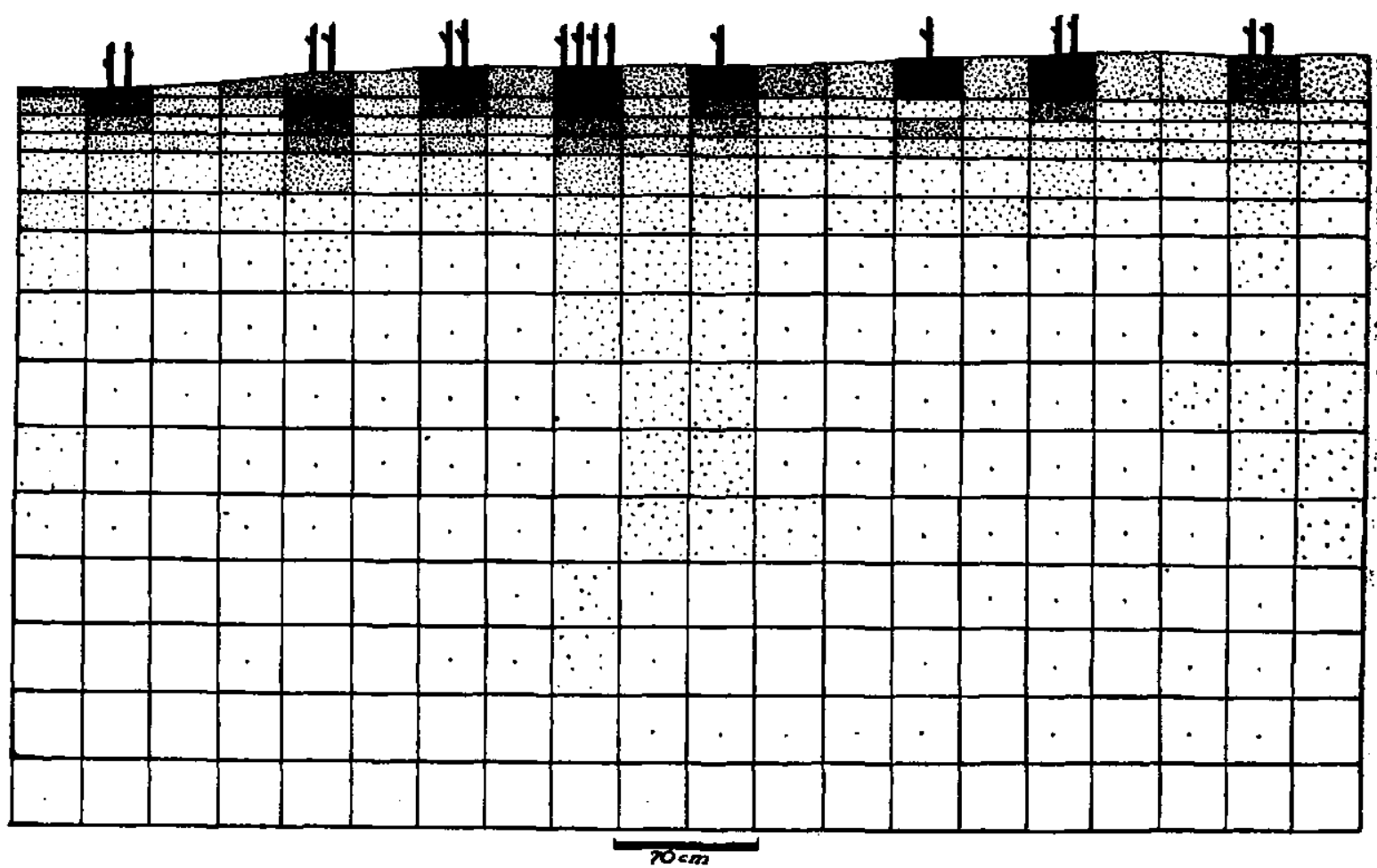

Fig. 1. - Gráfico do perfil do sistema radicular das 16 plantas de Tephrosia candida.

dos quais os mais importantes são as bactérias, os actinomicetos (3) e os: protozoários.

A matéria orgânica sofre várias transformaçoes antes de atingir completa decomposição. Pela ação dos microorganismos produzem-se $\mathrm{CO}_{2}$, nitratos e nitritos, etc. Finalmente, êstes se quebram em seus elementos. simples : $\mathrm{S}, \mathrm{P}, \mathrm{K}, \mathrm{Mg}, \mathrm{Ca}$, etc. (3).

Com a incorporação de adubo verde ao solo melhoram as condições: de vida dos microorganismos. Ativam-se os processos bioquímicos.

Uma leguminosa utilizada como adubo verde, além de oferecer essas. vantagens, pode trazer nódulos bacterianos nas raízes, enriquecendo o solo em $\mathrm{N}$ tirado do ar. Tephrosia candida D. C., nas condiçбes de Campinas, traz nódulos nas raízes.

Sousa (4) trabalhando com Tephrosia, chegou aos seguintes resultados de interêsse prático :

a) Aos 6 meses de idade ela fornece $37.671,72 \mathrm{~kg}$ de massa verde por alqueire ;

b) Aos 3 anos produz $181.016 \mathrm{~kg}$ de hastes e de massa verde por alqueire.

A luz dos nossos resultados e no caso de ser a planta utilizada como adubo verde, podemos acrescentar mais o seguinte :

c) Com 5 anos de idade, mais ou menos, quando plantada em linha e com espaçamento de $0,35 \mathrm{~m}$, forneceu ao solo $87.022 \mathrm{~kg}$ de raízes: por alqueire. 


\section{S U M ÁR I O}

$99,14 \%$ em pêso das raízes de Tephrosia candida D. C. se encontram nos primeiros $0,50 \mathrm{~m}$ de profundidade, em solo do tipo de terra roxa misturada. A profundidade máxima das raízes aí atingida foi de $3,85 \mathrm{~m}$. O pêso total das raízes de 16 plantas estudadas foi de $8.810,12$ gr. Assim, uma cultura da Tephrosia, em linha e no espaçamento de 0,35 , fornecerá ao solo, em 5 anos, o total de $87.022 \mathrm{~kg}$ de raízes ricas de nódulos bacterianos, por alqueire.

\section{LITERATURA CITADA}

1. Franco, C. M. e R. Inforzato. O sistema radicular do cafeeiro nos principais tipos de solo do Est. de S. Paulo. Bragantia 6 : 443-458. 1946.

2. Menezes Sobrinho, A. Cultivo racional do solo. Bol. Secr. Agr. Ind. e Com. do Est. S. Paulo n. s. : $43: 161-172.1942$.

3. Millar, C. E. e L. M. Turk. Em Fundamentals of soil science, pg. 1-492, 1. ${ }^{\mathrm{a}}$ edição, John Wiley \& Co., N. York. 1943.

4. Sousa, A. J. O emprêgo da Tephrosia candida D. C. na cultura cafeeira. Rev. do Dep. Nacional do Café 23 : 18̄̄-197. 1944.

5. Viégas, G. P. e N. A. Neme. A cultura da tefrósia em face da conservą̧ão do solo. Chácaras e Quintais 67: 300-303. 1943. 
Est. 14

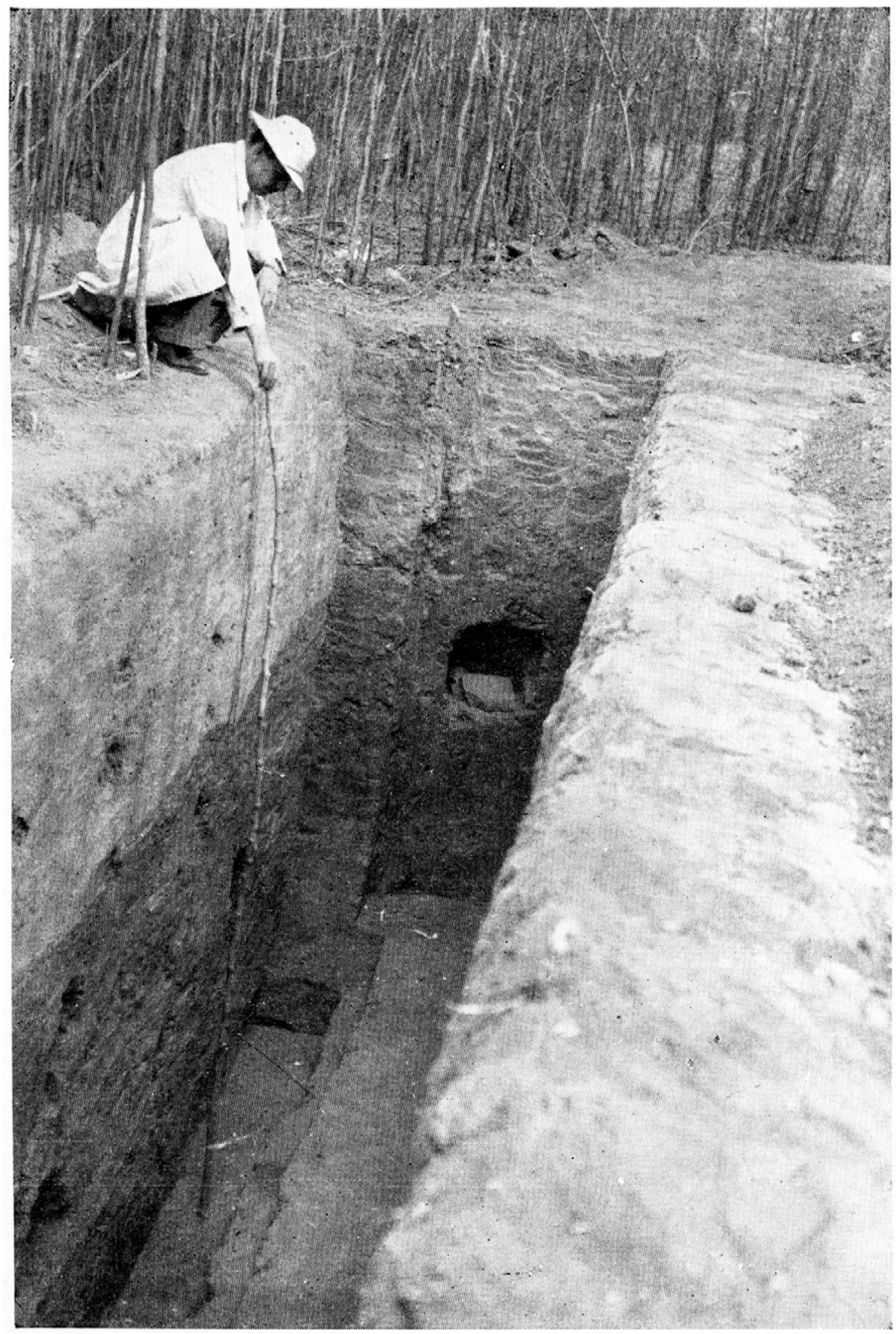

Valeta aberta ao lado das 16 plantas após a retirada dos blocos de terra. As cavida des mas paredes são volhas panelas de saúva. 


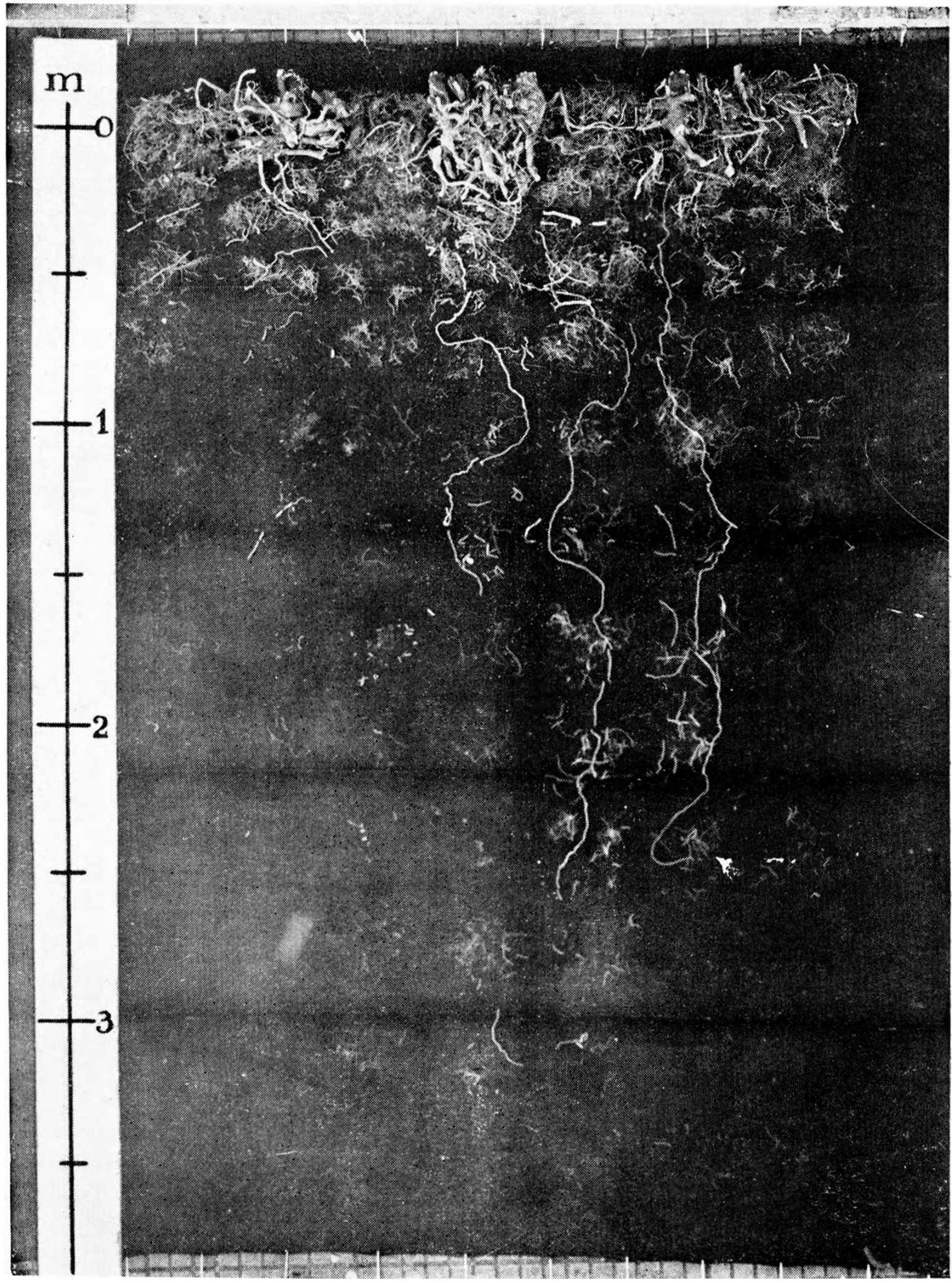

Distribuição das raízes de Tephrosia candida D. C. sôbre pano preto. Profundidade máxima atingida pelas raízes, $3,85 \mathrm{~m}$. 